\title{
A função psicológica do trabalho
}

[CLOT, Yves. PetrÛpolis, R] : Vozes, 2006. 222p.]

Daniela Diasdos Anjoš eRaquel Souza M agro*

Yves Clot é professor no Conservatoire National des Arts et M étiers (CN AM) em Paris, e integra o Laboratoire de Psychologie de Travail desta instituição, na qual, a partir de sua entrada, organiza-se uma equipe de Clínica da Atividade.

O s estudos do Prof. Clot no campo da psicologia do trabalho têm início na década de 80, momento em que entra em contato com os estudos de Ivar 0 ddone", que 0 inspira a "transformar a psicologia do trabal ho em psicologia dos trabalhadores" (M achado, 2005, p.157).

Em 1985, introduz a obra de Vygotski em seus estudos, com o objetivo de olhar para 0 "trabal ho como um campo essencial para o desenvolvimento do homem" (M achado, 2005, p.157) e é desse ponto de vista que constrói uma base de discussão teórica e metodológica para a análise psicológica do trabal ho.

N esse trabalho, o autor contextualiza suas idéias a partir das teorias da psicologia do trabal ho existentes, em especial a ergonomia, a fim de compreender e dialogar com essas abordagens, a partir das quais elabora sua própria análise. Com isso, Clot propõe o diálogo entre diferentes olhares em relação à análise da atividade, para depois, então, delinear sua própria perspectiva e expor sua proposta.

0 livro é dividido em três partes. $\mathrm{N}$ a primeira, Clot discute os limites e as contribuições das diferentes vertentes da psicologia ergonômica, bem como

* Doutoranda em Educação pela FE-Unicamp. Professora na Escola de Educação Infantil Casa da Gente - Campinas/SP. danjos04@yahoo.com.br.

* * Mestranda em Educação pela FE-Unicamp. Professora do Ensino Fundamental I no Colégio Rio Branco - Campinas/SP. raqmagro@uol.com.br

1. Médico responsável pela criação de um modelo operário italiano de luta pela saúde nos ambientes de trabalho. Clot refere-se ao trabalho realizado por Oddone na fábrica da Fiat de Turim que, segundo o autor, é um dos principais elementos para o seu trabalho atual. Oddone, I; Rey, A. e Briante, G. Redécouvrir l'expérience ouvrière. Vers une autre psychologie du travail. Paris : Editions Sociales. (1980) 
apresenta os aportes teóricos que sustentam a psicologia do trabalho que ele procura desenvolver. U ma das principais idéias discutidas é a não-abordagem das dimensões subjetivas da atividade, uma vez que as diferentes vertentes da psicologia ergonômica foram fundadas a partir da psicologia cognitiva e da psicologia do trabalho francesa que, segundo ele, apresentam uma dicotomia entre a vida no trabalho e a vida fora dele. Segundo o autor, a atenção à subjetividade é fundamental e levará a uma revisão do conceito de atividade até então desenvolvido pela ergonomia e pela psicologia do trabalho. Assim, "O trabalho não é uma atividade entre outras. Exerce na vida pessoal uma função psicológica específica que se deve chegar a definir. E isso, precisamente, em virtude de ser ele uma atividade dirigida" (p. 12).

$\mathrm{N}$ a segunda parte do livro, Clot apresenta o conceito de atividade como unidade de análise. Essa é entendida como tendo três direções: pelo sujeito, para o objeto e para os outros.

A atividade dirigida participa portanto detrês vidas ao mesmo tempo (a do objeto, do sujeito ea dos outros), mobilizando 0 gênero de atividades adequado à situação. No entanto, é necessário vêla como um todo singular em quecada um dos elementostem sempreos dois outros como pressupostos(p.102)

0 gênero, idéia reelaborada a partir da noção de gênero do discurso de Bakhtin², seria a história da atividade compartilhada por determinado grupo de trabalhadores. N essa história, incluem-se regras implícitas, modos de dizer, modos de fazer, anseios, expectativas. Através do gênero, cada sujeito pode predizer e antecipar - parcialmente, ao menos - os resultados de sua ação. De acordo com o autor o gênero é

o sistemaaberto de regrasimpessoais snão escritas quedefinem,
num meio dado, o uso dos objetos e o intercâmbio entre as
pessoas: uma forma de rascunho social que esboça as relações
doshomensentresi para agir sobreo mundo. Pode-se defini-lo
como um sistemaflexível de variantesnormativase dedescrições
que comportam vários cenários eum jogo deindeterminação
quenosdiz dequemodo agem aquelescom quem trabalhamos,
como agir ou deixar de agir em situações precisas; como bem
realizar as transações entre colegas detrabal ho requeridas pela

2. Segundo Bakhtin, cada "campo de utilização da língua elabora seus tipos relativamente estáveis de enunciados, os quais denominamos gêneros de discurso". Tais enunciados refletem as condições e as finalidades de cada referido campo, através de seu conteúdo temático, do estilo da linguagem e da construção composicional, elementos esses "indissoluvelmente ligados" (Bakhtin, 2003, p.261-262) 
vida em comum organizada em torno de objetivos de ação. (Clot, 2006, p. 50)

Assim, a noção de gênero de atividade, idéia discutida durante todo o livro, está diretamente ligada à função psicológica do trabalho, já que essa função se encontra justamente na participação do sujeito num dado gênero.

C adaum sevêpor meio de suas próprias atividades no interior da divisão do trabal ho simultaneamente como sujeito e como objeto dessa conservação edessa invenção. É por isso que, para nós, o exameda divisão social do trabalho - suadistribuição em gêneros dediferentes atividades, subordinados, hierarquizados, mastambém moventesemóveis- éabsolutamentedecisivo em termos deanálise dasatividades profissionais poisé, dealguma maneira, seu fundamento. 0 trabalho éfeito em sociedadee estaéprimordial mentecoletiva (p.80-81).

A partir desse quadro teórico, Clot descreve seus instrumentos de pesquisa no interior daquilo que chama de Clínica da atividade, na qual são realizadas análises, a partir das reflexões dos sujeitos, sobre suas próprias ações no interior de um campo de atividade profissional.

Tais instrumentos (autoconfrontação clássica, autoconfrontação cruzada e instrução ao sósia) têm por objetivo promover a compreensão de efeitos de sentido que circulam em uma atividade de trabalho. Nos três casos, o que se busca é dar um lugar privilegiado à palavra, ou seja, o diálogo deixa de ser objeto de pesquisa e assume o lugar de método. É através da enunciação de sua ação que 0 trabalhador traz as realidades do trabalho, podendo assim refletir sobre os gêneros, para que eles permaneçam, voltem a ser ou passem a ser um meio de ação coletiva ou individual em determinada situação. "A verbalização é em si mesma uma legítima atividade do sujeito, e não apenas um meio de acesso a outra atividade" (p.135).

$\mathrm{N}$ a última parte do livro, Clot desenvolve a questão da ação do sujeito e do estilo na reconstrução do gênero, a qual ocorre pela invenção estilística do sujeito em uma atividade de trabalho. No entanto, para isso, faz-se necessário o domínio do gênero e supõe-se a participação em vários gêneros concomitantemente. Esta invenção estilística garante a sua variedade, flexibilidade e renovação.

Assim, é através desses instrumentos e dos conceitos descritos nesse livro que Yves Clot desenvolve uma obra que, ao mesmo tempo, volta-se para a subjetivação e para a organização do trabalho.

O livro não faz uma referência direta ao trabalho do professor, porém traz subsídios teóricos e metodológicos para dar continuidade a uma discussão que 
foi elaborada por pesquisadores brasileiros que têm buscado pensar o ensino como uma atividade de trabalho, com especificidades e características próprias; e o professor como um trabalhador e, portanto, inserido em um gênero e portador de estilos (M achado, 2005).

\section{Referências bibliográficas}

BAKH TIN , M ikhail. O sgênerosdo discurso. Estética da criação verbal. 4.ed. São Paulo: M artins Fontes, 2003.

M ACH AD O , AnnaR Rquel (org). 0 ensino como trabalho: uma abordagem discursiva. Londrina: Eduel, 2004.

M ACH AD O , Anna Raquel. Entrevista com YvesC lot. Psicologia da Educação, São Paulo, 20, p.155-160, 1‥ semestre de 2005. 